Anales de Geografía de la Universidad Complutense ISSN: 0211-9803

http://dx.doi.org/10.5209/AGUC. 62485

\title{
Los nombres de lugar: un recurso didáctico en la enseñanza geográfica del paisaje natural
}

\author{
Antoni Ordinas Garau ${ }^{1}$; Jaume Binimelis Sebastián \\ Recibido: 30 de abril del 2017/ Enviado a evaluar: 14 de junio del 2017/ Aceptado: 18 de octubre del 2018
}

Resumen. A partir de la experiencia en recopilación toponímica se descubre no sólo la estrecha relación entre la toponimia y la ciencia geográfica sino también las posibilidades didácticas que los nombres de lugar, también conocidos como nombres geográficos, ofrecen para la enseñanza de la Geografía. Nuestra aportación se centra en sistematizar las diversas áreas temáticas del medio natural que se pueden abordar desde el análisis y estudio de los topónimos que caracterizan un determinado territorio, tanto si el aprovechamiento didáctico se basa en un grupo concreto de ellos como si se consideran en su conjunto. Su aplicación como recurso en la didáctica de la Geografía contribuye a dotar al alumnado de un mayor y más profundo conocimiento tanto del paisaje natural como del territorio que ocupa.

Palabras clave: Nombres de lugar; Geografía; recurso didáctico; paisaje natural.

\section{[en] The place names: a didactic resource in the geographical education of the natural landscape}

\begin{abstract}
From the experience creating a toponymic collection is discovered not only the close connection between toponymy and geographical science but also the educational possibilities that place names, also known as geographical names, provide to teach Geography. Our contribution focuses on systematizing the diverse thematic areas of the natural environment that can be addressed from the analysis and study of toponyms that typify a certain territory, whether the academic progress is based on a particular group of them or if they are considered as a group. Its application as a resource in Geography didactics helps to supply the students with a greater and deeper understanding of both the natural landscape and the territory it takes up.
\end{abstract}

Key words: Place names; Geography; educational resource; natural landscape.

1 Departamento de Geografía. Universidad de las Islas Baleares.

E-mail: antoni.ordinas@uib.es 


\section{[fr] Les noms de lieux: une ressource didactique dans l'éducation géographique du paysage naturel}

Résumé. À partir de l'expérience acquise en matière de recueil toponymique, nous découvrons non seulement la relation étroite qui existe entre la toponymie et les sciences géographiques mais aussi les possibilités didactiques qu'offrent les noms de lieux, également connus sous la dénomination de noms géographiques, dans l'enseignement de la géographie. Notre contribution vise à systématiser les différents domaines thématiques du milieu naturel susceptibles d'être abordés à partir de l'analyse et de l'étude des toponymes qui caractérisent un territoire déterminé, aussi bien dans le cadre d'une exploitation didactique basée sur un groupe concret que dans leur ensemble. Son application en tant que ressource dans la didactique de la géographie contribue à doter l'élève d'une connaissance plus large et plus profonde aussi bien du paysage naturel que du territoire occupé par celui-ci.

Mots clefs: Noms de lieux; Géographie; ressource didactique; paysage naturel.

Cómo citar. Ordinas Garau, A. y Binimelis Sebastián, J. (2018): Los nombres de lugar: un recurso didáctico en la enseñanza geográfica del paisaje natural. Anales de Geografía de la Universidad Complutense, 38(2), 385-408.

Sumario. 1. Binomio toponimia-Geografía: una estrecha relación. 1.1. La utilidad didáctica de los nombres de lugar en el proceso de enseñanza-aprendizaje de la geografía. 1.2. El papel de la toponimia en la localización e identificación del territorio y en la terminología geográfica. 1.3. Los nombres de lugar en la cartografía. 1.4. La función descriptiva de los nombres de lugar. 2. Objetivos y metodología. 3. Resultados: la diversidad geográfica de los nombres de lugar y su potencialidad didáctica. 3.1. La oronimia: la morfología del terreno. 3.2. La geotoponimia: composición y alteración del terreno. 3.3. La hidronimia: la presencia del agua. 3.4. La biotoponimia (fitotoponimia y zootoponimia): la naturaleza viva. 3.5. La toponimia meteorológica. 3.6. La toponimia relativa a la exposición solar. 3.7. La toponimia sobre la percepción del paisaje. 4. Conclusiones. 5. Bibliografía.

\section{Binomio toponimia-Geografía: una estrecha relación}

El hombre, desde sus orígenes, ha identificado los lugares que iba conociendo mediante los nombres que la sociedad impuso para este menester. Unos nombres frecuentemente descriptivos que surgen, a la par que la ciencia geográfica, como respuesta a la necesidad de organizar este saber (Sauer, 1985). Pero aunque el interés y estudio de los topónimos (comunmente conocidos como nombres de lugar o también, y de forma todavía más significativa, nombres propios geográficos) cuenta ya con una larga trayectoria, ésta se ve sensiblemente reducida si se aborda desde el ámbito científico de la geografía y aún más al circunscribirlo en el entorno geográfico español. De la fecunda interdisciplinariedad de la toponimia participa, jugando un destacado papel, la ciencia geográfica como ya señaló el inglés H.C. Darby (1957) a la vez que advertía de las limitaciones a la que se podía someter el estudio toponímico enfocado desde una perspectiva exclusivamente filológica y sin tener en cuenta la necesaria participación del análisis geográfico. Y no fue el único. Figuras tan relevantes de la Geografía como Paul Vidal de la Blache, Carl Sauer, Paul Claval, Henri Dorion o Pau Vila, entre otros, han compartido la reivindicación del valor geográfico de los nombres de lugar y de la estrecha relación entre geografía y 
toponimia. Entre los autores ya citados destaca de forma especial la obra del geógrafo canadiense Henri Dorion -todo un referente a nivel internacional por sus aportaciones en el campo de la toponimia aplicada a la geografía y sobre las que se fundamentan importantes principios teóricos-, quien afirma al respecto:

Mi objetivo es exponer aquí a los incesantes usuarios de toponimia como son los geógrafos que la geografia necesita de la toponimia, pero también y sobre todo que la toponimia necesita del geógrafo, especialmente del profesor de geografia (...) La toponimia constituye, por tanto, al respecto, una herramienta educativa nada despreciable que, a nuestro parecer, debe ser valorada como importante. Hay fuentes cada vez más numerosas, válidas y fácilmente disponibles para orientar a profesores y estudiantes en materia toponímica (Dorion, 1986: 429).

En esa misma línea innovadora han surgido algunas corrientes geográficas como la denominada"geografía del lugar" (Tort, 2002) que abogan por abordar en profundidad el estudio toponímico desde un prisma geográfico. Mucho antes, Paul Vidal de la Blache (1888-1889), impulsor de la escuela regional francesa, ya se refería a los topónimos como "fuentes vivas de la geografía" al tiempo que descubría la profunda imbricación entre el país y sus nombres, una conexión que equivale, a distinta escala, a la que se establece entre los lugares y sus topónimos.

El vínculo entre la Geografía y la Toponimia también fue reivindicado por los geógrafos norteamericanos, entre los que destaca Carl O. Sauer, padre de la geografía cultural, para quien el vocabulario geográfico local y la toponimia constituyen un sustrato de saber que evidencia la estrecha relación entre la terminología geográfica y la toponimia (Sauer, 1956). Asimismo, a inicios de la década de los años 50, R.C. West, (1954) defendió la estrecha relación entre los nombres de lugar y la Geografía en un estudio sobre la distribución del topónimo "bayou", término que designa los cauces lentos de los ríos, especialmente los situados en las características llanuras de inundación en Louisiana, en torno al delta del Mississipi, afirmando que la clasificación y distribución de los nombres de lugar pertenece al campo de la Geografía, mientras que el estudio de su etimología corresponde al mundo de la Filología.

Por otra parte, Rose-Redwood et al. (2010) explican como la toponimia ha abandonado su vía tradicional, basada en estudios sobre taxonomia y etimología para inaugurar un ciclo de estudios críticos ("critical turn") más centrados ahora en la visión crítica de las razones políticas que subyacen en los nombres de lugar. A mediados de los 80 varios investigadores se planteaban la razón de los nombres de las calles en trabajos de toponímia urbana. En los 90, ahondando en este interesante enfoque, ligaron el estudio de la toponimia al ejercicio del poder. En esta línea se ha hecho especial hincapié en los cambios en los nombres de las calles como reflejo de los cambios en el poder político, constatando como éste usa el cambio de nombre como mecanismo para naturalizar su hegemonía. La lectura ideológica como forma de investigar la dimensión sociopolítica de los signos forma parte de esta perspectiva semiótica aplicada recientemente a los nombres de lugar. Se descubre la toponimia 
como una herramienta de gobernabilidad al formar parte de la historia de los sistemas de identificación espacial al igual que la numeración de las casas o los parcelarios para el ordenamiento de la propiedad (Geo-coding). Paralelamente, los topónimos también pueden ser un ejemplo de confrontaciones entre grupos sociales hegemónicos y otros subordinados a ideologías contra-hegemónicas. Se llega a calificar de guerra de topónimos cuando uno de estos grupos marginados, perteneciente a minorías nacionales o lingüísticas, logran apropiarse de un topónimo. Sería, por ejemplo, el caso de la lucha reinvindicativa de la población afroamericana en favor de homenajear a Martin Luther King, dando su nombre a una calle. De esta forma, Alderman (2000) analiza la distribución de calles conmemorativas del líder negro en todo el país para luego centrarse en las calles de once estados del Sur, analizando el nivel de renta y el componente racial de sus habitantes, así como la funcionalidad de la calle (negocios, residencial). Los resultados muestran que las calles Martin Luther King se localizan en áreas de gente pobre y mayoría de población afroamericana, contraviniendo los deseos de los líderes negros, que reclaman el nombre de King para una vía urbana frecuentada y céntrica. Sahul Cohen i Nurit Kliot (1992), por otra parte, explican como la lucha del poder por los nombres de lugar en el conflicto árabe israelí se recrudeció tras la Guerra de los seis días de 1967. Las comunidades judías auspiciadas por el Likud recuperaban topónimos de la Biblia y del Talmud para acrecentar la relación de los colonos con las tierras ocupadas.

En el contexto de la geografía española, aunque algo tardío, en los últimos años se ha producido un interés creciente por la toponimia coincidiendo con la incorporación de jóvenes geógrafos y un importante número de trabajos por ellos realizados. Destaca, por sus aportaciones epistemológicas y metodológicas relativas a la toponimia, J. Tort (2003), quien ha subrayado el destacado papel de los nombres de lugar como fuente descriptiva y explicativa de los paisajes y de sus respectivos territorios. Paralelamente, otros ya veteranos geógrafos toponimistas como V.M. Rosselló (2004), con abundante producción en la materia, se ha convertido en referente ineludible cuando inicialmente, en un contexto académico de marginalidad de la toponimia, ha abanderado la compatibilidad entre el oficio de geógrafo y el interés por el estudio de los topónimos. Todos ellos han colaborado en la puesta en valor de los nombres de lugar como herramienta para descubrir la organización cultural que subyace en unos paisajes modelados a lo largo de los tiempos.

\subsection{La utilidad didáctica de los nombres de lugar en el proceso de enseñanza- aprendizaje de la geografía}

Después de haber trabajado sobre cualquier aspecto relacionado con la toponimia (recopilación, análisis territorial, aplicación cartográfica...), un geógrafo percibe de inmediato las potencialidades que los nombres de lugar ofrecen en el proceso de enseñanza-aprendizaje, destacando especialmente su utilidad en el conocimiento del medio, tanto en la adquisición de conceptos y terminología, como en procedimientos y valores en la didáctica de las Ciencias Sociales (Friera, 1992). Así, la enseñanza 
basada en los topónimos permite la consecución de objetivos conceptuales como la identificación del medio, natural y humano, a través de su denominación, y el impacto de las actividades antrópicas sobre el medio físico así como las transformaciones experimentadas a lo largo del tiempo, cualidades que, como recomienda Dorion (2007) deben ser conocidas entre el alumnado de las nuevas generaciones. Además, el conocimiento profundo del territorio a través de su toponimia contribuye a despertar el sentimiento de apego, pertenencia e integración en una determinada comunidad, a la vez que estimula la topofilia (Tuan, 1974) como consecuencia de los procesos de apropiación e identificación del individuo con un espacio o lugar determinado. La valiosa información obtenida de los topónimos sobre múltiples aspectos del territorio, de su geografía y su historia -la denominada función pedagógica de la toponimia-, constituye una importante contribución a la consolidación de la conciencia territorial, base esencial de la cohesión y la coherencia social.

Por otro lado, y desde el punto de vista de la escala, la diferenciación entre toponimia mayor o macrotoponimia y toponimia menor o microtoponimia permite distinguir entre los distintos enfoques de aplicación didáctica al conocimiento del territorio. Mientras que a través del estudio de la macrotoponimia se puede contribuir al conocimiento global, geográfico, de territorios lejanos y ajenos, mediante la microtoponimia se alcanza el conocimiento intensivo y exhaustivo del territorio cercano. En definitiva, la aprehensión del territorio necesita de la toponimia de forma que sin nombres de lugar resulta muy difícil catalogar y archivar la información geográfica.

Sin embargo, desgraciadamente, la utilización de la toponimia en la enseñanza ha ido tradicionalmente asociada a un aprendizaje exclusivamente memorístico de los nombres de lugar. Durante mucho tiempo se enseñó una geografía de los nombres, cuyos manuales escolares estaban repletos de listas de topónimos que identificaban mares, ríos, cordilleras... además de países y sus capitales, ciudades, regiones... que el alumnado debía memorizar para poder aprobar exámenes y asignaturas. Se postulaba así una concepción corológica de la geografía asociada a la visión descriptiva -idiográfica y especial, siguiendo la dicotomía kantiana-, y enfatizando el enfoque regional. Posteriormente, la oposición y reacción a esta fórmula llevaría al desarrollo de una geografía más relacional y conceptual, mejor preparada en métodos correlativos, cuantitativos e informáticos $\mathrm{y}$, en definitiva, más atractiva didácticamente. Pero la revolución pedagógica que ello supuso tuvo, no obstante, un rehén: la toponimia, que asociada al abuso de la práctica memorística, sería proscrita y relegada a un papel secundario como revulsivo al protagonismo del que había gozado durante tanto tiempo. La nueva situación, no exenta de cierta radicalidad, conllevaría el abandono de la toponimia como recurso didáctico $\mathrm{y}$, en consecuencia, empezarían a evidenciarse los importantes déficits del alumnado en el conocimiento del territorio a través de los nombres geográficos (Dorion, 1986), carencias que todavía persisten en la actualidad. Una vez detectado el problema, en algunos países como Canadá y Estados Unidos -en este último con cursos sobre "Place name geography"-, recuperaron en su enseñanza el interés por su "tesoro toponímico" como 
parte del siempre valioso patrimonio cultural, de forma que en algunas webs, como la de la Comisión de Toponimia de Canadá, se ofrecen todo tipo de recursos para el mundo de la enseñanza relacionados con la toponimia, en unos servicios en línea admirables. También en Canadá se ha reinvindicado la necesidad de recuperar los topónimos indígenas de la cultura Dakelh, al Oeste del país, con el objetivo de revitalizar la toponimia tradicional indígena, sustituída por la colonización, como herramienta de educación para niños y adolescentes, y así reforzar sus signos de identidad (Heikkila,1995).

Algo similar ocurre en l'Ordnance Survey británica, donde a través de la toponimia se vehiculan informaciones culturales y geográficas con enlaces dirigidos a la búsqueda y visualización cartográfica. En el caso de la Comisión de Nombres Geográficos de Australia, se incrementan las posibilidades con todo tipo de recursos relacionados con la toponimia del país especialmente dirigidos a alumnos y docentes, así como la difusión de documentales donde se descubre la toponimia nacional y en los que se conciencia del valor patrimonial y de la necesidad de preservar las formas autóctonas de sus topónimos (Parella, 2008). En Rumanía, asimismo, se reconoce en los topónimos un factor especial de orientación y un fundamento de largo recorrido en el aprendizaje y en la enseñanza (Enica, 2011).

\subsection{El papel de la toponimia en la localización e identificación del territorio y en la terminología geográfica}

La función de localización e identificación de la toponimia es tan evidente como fundamental. Las herramientas que garantizan su exactitud se apoyan en la cartografía, sobretodo a gran escala, en la que los rótulos toponímicos constituyen una de las principales capas de un mapa topográfico. De ahí que haya quien se ha referido a los topónimos como "etiquetas del lugar" (Valenzuela, 2010) no solamente en el sentido identificativo de la expresión sino también en el explicativo. El hecho de asignar nombres a los lugares es una constante en todos los tiempos y culturas por el imperativo que supone identificar cada lugar e integrarlo en el proceso de comunicación. $\mathrm{Y}$ en ese proceso, la elección del nombre, en su origen, no era al azar sino que respondía a la percepción de la realidad, aludiendo al rasgo o a los elementos más sobresalientes con un marcado sentido descriptivo, a veces metafórico -pero que llega a ser abundante y significativo en los genéricos toponímicos del medio físico-, en el que se observan las influencias perceptivas y culturales de los pobladores.

La riqueza y utilidad de la información proporcionada por los topónimos sobre los lugares que designan, sobre la sociedad que los creó, sobre los motivos que los han originado (la llamada etiología), difundido y transformado no sólo es susceptible de aprovechamiento didáctico sino que debería incluirse de forma más patente en los planes de estudio a todos los niveles a tenor de las deficiencias observadas al respecto en la formación de nuestros jóvenes. Como indica Dorion (1986), subrayando la función de identificación y localización de la toponimia, ¿qué valor pedagógico 
tendría un curso de historia política, de economía o de geografía, repleto, como debe ser, de ejemplos que el estudiante sería incapaz espontáneamente de localizar?

Además del ya mencionado Sauer, son muchos los geógrafos que han advertido la relación esencial entre la geografía y la toponimia, al forjar ésta los nombres de lugar $\mathrm{y}$, a partir de sus genéricos o apelativos, el vocabulario propio de la primera, a veces bajo las denominaciones genéricas de ciencias de la tierra o "lenguaje del territorio". Coincidiendo con Tort (2001), quien a su vez cita a Berdoulay (1982), el estudio del lenguaje geográfico, a pesar de su transcendencia epistemológica, no ha sido todavía objeto de estudio profundo. No obstante, en nuestro caso y como fruto de una vasta tarea de recopilación toponímica llevada a cabo en las Islas Baleares, tuvimos la ocasión de abordar este campo de estudio (Ordinas, 2001) y constatar algunas de sus particularidades y, entre ellas, a la que se refieren los autores antes reseñados relativa al importante uso de la metáfora en la nomenclatura toponímica y, por ende, en la terminología geográfica. Algunos geógrafos hemos investigado y depurado las denominaciones regionales presentes en la toponimia, obteniendo resultados especialmente fecundos en la formación del vocabulario geomorfológico (Ordinas, 2004).

\subsection{Los nombres de lugar en la cartografía}

Además del binomio geografía-toponimia, existe asimismo un estrecho vínculo entre toponimia y cartografía y entre ésta y la geografía, conformando los vértices de un triángulo ya clásico de interdisciplinariedad. Hasta comienzos del siglo XIX, el oficio de geógrafo se asimilaba al de mapista, eso es, un redactor y compilador de mapas y cartas. Y en cartografía, en los mapas topográficos, la toponimia, junto a la planimetría y la altimetría son sus tres componentes básicos. En ese sentido, poco hay más elocuente, y paradójico a la vez, que calificar de mudo a un mapa sin toponimia. $Y$ es que el cartógrafo necesita de los nombres geográficos, pues sin ellos resulta muy difícil identificar los detalles y lugares representados en los mapas (Raisz, 1985). Incluso se ha calificado a la toponimia como la sangre de la cartografía (Rosselló, 2004), pues no en balde, en su estrecha relación para fijar el conomiento del territorio, destacan la recolección, localización, clasificación, jerarquización y distribución de los nombres geográficos. Para estos menesteres resulta particularmente adecuada la implicación de los geógrafos. Estudiosos de la toponimia, como el británico Sir Allen Mawer, ya alertaron del riesgo de una aproximación exclusivamente filológica, debido a la necesidad del conocimiento y reconocimiento directo de los topónimos y sus enclaves. Incluso en aspectos eminentemente filológicos como es la etimología, las conclusiones del filólogo deben ser contrastadas con la realidad topográfica, ya sea a través de mapas o, preferentemente, del imprescindible trabajo de campo, competencias ambas inherentes al ejercicio de la geografía. Son numerosos los ejemplos donde se demuestra que el conocimiento pleno y directo del territorio descubre las claves del significado y la etiología de los topónimos y como las 
hipótesis formuladas respecto a sus etimologías pueden resultar erróneas sin el respaldo de las necesarias comprobaciones in situ.

\subsection{La función descriptiva de los nombres de lugar}

Tan fundamental como evidente resulta la función descriptiva de la toponimia, pues como ya hemos señalado, cada nombre de lugar contiene información que refleja la estrecha relación entre el hombre y el fragmento del territorio o lugar a partir del momento en el que ha sido identificado mediante la asignación de un nombre propio. A partir del simple hecho de asignarle un nombre, la toponimia transmite las propiedades del lugar que identifica. Nombrar los lugares, según Claval (1995), es impregnar de cultura y poder el espacio. Más aún, la información que se deriva del análisis toponímico revela datos geográficos, hechos y acontecimientos históricos y sociales, de tal manera que se convierten en una vía de acceso al contexto geo-sociohistórico de un lugar o región en su dimensión espacio-temporal (Dorion, 1986).

$\mathrm{Si}$, por una parte, el estudio y análisis de la toponimia evidencia como una importante proporción y número de topónimos presentan un carácter eninentemente descriptivo (Tort, 2000), ya se ha apuntado, por otra, tanto la equivalencia entre las denominaciones de nombres de lugar y nombres geográficos como la identificación entre geografía y descripción de la tierra. A partir de ambas proposiciones se forma el silogismo por el que se infiere la estrecha relación entre la toponimia y la descripción que convierte en relevante y significativa la utilidad de la toponimia como fuente de información y descripción del territorio. Y si a ello añadimos la riqueza y calidad de la información geográfica extraída de los topónimos, nos encontramos ante una fuente de información de primer orden para el análisis detallado del territorio y su estudio geográfico, equiparable a cualquier otra $\mathrm{y}$, en cualquier caso, complementaria. Si resulta obvio considerar la descripción como un método adecuado en la formación del conocimiento geográfico, no lo es menos el potencial de los nombres de lugar en dicho conocimiento por su importante contribución en la descripción de los lugares que asimismo localizan e identifican.

No obstante, resulta también evidente que no todos los topónimos presentan el mismo grado de transparencia y facilidad de obtención de la información, pues los hay ininteligibles al pertenecer a antiguas culturas y estratos lingüísticos mostrando una mayor opacidad y resistencia a transmitirla. Aún así, el estudio y consulta de su etimología a partir de diccionarios y obras especializadas permite en muchos casos superar estos obstáculos y desencriptar la información oculta tras sus nombres.

\section{Objetivos y metodología}

Tal como indica la propia etimología -del griego ' $\tau$ ó $\varsigma^{\circ}$ ' (topos), lugar, y ' $v о \mu \alpha$ ' (onoma), nombre-, la toponimia implica una evidente interdisciplinariedad en la que la localización geográfica se erige en uno de los rasgos básicos que de forma intrínseca conforman los topónimos, aunque el papel científico y pedagógico de la 
geografía va mucho más allá de la simple localización. De este modo, a la tradicional función identificadora de los topónimos que algunos autores como Dorion (1986) también denominan función locativa o de localización, debe agregarse una función descriptiva (a veces también llamada de comunicación) y, por tanto, de carácter eminentemente geográfico al entroncar con la etimología misma de la geografía, 'descripción de la Tierra'. En este punto debemos recordar, por una parte, que la descripción, desde los orígenes de la ciencia geográfica, ha sido el método utilizado en la formación del conocimiento geográfico y, por otra, que la mayoría de los nombres de lugar son descriptivos, aunque no todos presenten el mismo grado o nivel de descripción, característica que permite diferenciar entre topónimos completamente descriptivos y los que sólo lo son en parte o indirectamente (Tort, 2000), además de aquellos que puedan carecer de esta capacidad. A partir de la obtención e interpretación de la información contenida en las dos primeras tipologías, el geógrafo extrae numeroso y preciado material relativo a la composición y distribución del territorio, lo que le permite caracterizar su paisaje y estudiar los cambios que se hayan producido, incluso en las actividades humanas que lo configuran (Ordinas y Binimelis, 2002). Se constata, por tanto, como la abundante fuente de información que se consigue a través del análisis detallado de todos y cada uno de los topónimos de una región así como de su conjunto, aborda cualquier aspecto, físico o humano, susceptible de estudio y análisis geográfico.

De esta forma, el estudio y análisis de la toponimia permite acceder a una importante y variada reserva de información geográfica que, además, cuenta con el valor añadido de articularse con la función de localización de la toponimia. Desde esa premisa el alumnado, además de practicar y adiestrarse en la localización e identificación, también cartográficas, podrá adquirir conocimientos a nivel local y regional del contexto geográfico e histórico pues, sin duda, una enseñanza apoyada en la toponimia amplia y refuerza los contenidos propios del conocimiento del medio relativos al medio físico así como el paisaje y sus cambios históricos, entre otros. A partir de la relación entre los nombres de los lugares y lo que se enseña en geografía y de acuerdo con la perspectiva psicopedagógica constructivista, el primer paso a realizar consistirá en averiguar el grado de conocimiento de los alumnos respecto a la toponimia de su propio entorno. A partir de ahí, podremos desvelar las claves que la toponimia ofrece para la observación e interpretación de la complejidad de los paisajes naturales y culturales, facilitando a su vez la observación directa del medio. Resulta particularmente adecuada la aplicación del análisis de la toponimia para el estudio del espacio geográfico más próximo al alumno (calle, barrio, pueblo o ciudad, municipio, región...) que podrá localizar en un mapa e investigar el significado de los nombres así como su etiología para comprobar su relación con las características ambientales y culturales del entorno.

En cualquier caso, para el estudio, análisis y clasificación de los topónimos (a partir tanto de su parte genérica, de donde se nutre buena parte de la terminología geográfica, como de su parte determinante, en los casos que la hubiera), ante la escasez y simplicidad de propuestas didácticas al respecto, presentamos un modelo de 
clasificación, confeccionado a partir de nuestra propia experiencia en la recolección y sistematización de la toponimia balear. La fuente de donde se extraen los topónimos del archipiélago balear es una base de datos constituida por unos 50.000 topónimos como fruto de la recolección toponímica más reciente y exhaustiva realizada para la confección del Mapa Topográfico Balear (MTB) a escala 1:5.000. Para realizar dicha recopilación toponímica, en la que participamos personal y directamente tanto en el trabajo de campo como en las diversas tareas de dirección y coordinación, se consultaron las principales obras cartográficas como punto de partida para localizar y cotejar los topónimos en ellas presentes e incrementar su número y densidad a partir de centenares de entrevistas efectuadas mayoritariamente sobre el terreno a otros tantos informadores, en la mayoría de casos previamente seleccionados por su especial conocimiento de una determinada área del territorio sobre la que fueron interpelados. Se trata, por tanto, de un análisis que parte del corpus toponímico actual aunque su origen debe buscarse en elementos tanto contemporáneos como pasados, ya que en la toponimia quedan fijados elementos de la realidad paisajística y humana pretérita.

\section{Resultados: la diversidad geográfica de los nombres de lugar y su potencialidad didáctica}

Como resultado del análisis y clasificación de la toponimia balear surge la propuesta que planteamos, abierta y flexible, ya que puede ser adaptada y ampliada a las particularidades de cada territorio a la vez que permite captar la diversidad de posibilidades que presenta la información contenida en la toponimia para el estudio geográfico del paisaje natural y un mejor conocimiento de sus elementos y del territorio que bajo él subyace.

Tabla 1. Toponimia del paisaje natural: bloques temáticos.

\begin{tabular}{|c|c|}
\hline $\begin{array}{c}\text { Toponimia del paisaje natural: bloques } \\
\text { temáticos }\end{array}$ & $\begin{array}{c}\text { Islas Baleares } \\
\mathbf{( \% )}\end{array}$ \\
\hline Orónimos: la morfología del terreno & 55 \\
\hline $\begin{array}{c}\text { Geotopónimos: la composición y alteración } \\
\text { del terreno }\end{array}$ & 17 \\
\hline Hidrónimos: la presencia del agua & 8 \\
\hline Biotopónimos: la naturaleza viva & 16 \\
\hline $\begin{array}{c}\text { La meteorología y la incidencia de los } \\
\text { fenómenos atmosféricos sobre el territorio }\end{array}$ & 1 \\
\hline La exposición solar & 2 \\
\hline La visión panorámica del paisaje & 1 \\
\hline
\end{tabular}

Fuente: Elaboración propia a partir del MTB 1:5.000 
Así, de la amplia gama de genéricos toponímicos e informaciones relativas a la geografía física presentes en los nombres de lugar, se pueden distinguir, tal como recoge la Tabla 1, los principales bloques temáticos así como los porcentajes toponímicos obtenidos para cada uno de ellos en las Islas Baleares.

Mediante dicho proceso de análisis y clasificación de la toponimia balear se perfilan no sólo los grandes bloques temáticos del paisaje natural sino también diversos apartados y subapartados que permiten diseccionar y pormenorizar los elementos paisajísticos a través de la descripción que ofrecen los topónimos, dando como resultado una gran riqueza de informaciones y de matices.

\subsection{La oronimia: la morfología del terreno}

Al desarrollar cada uno de estos bloques, se va descubriendo con más detalle la gran diversidad de información latente en la toponimia. Empezando por la oronimia, como conjunto de topónimos relativos a la morfología del terreno, cabe destacar su amplia y numerosa representación terminológica que aparece en la parte genérica de los topónimos y que permite identificar cualquier accidente del relieve, haciendo uso a menudo de la metáfora que es el origen, próximo o lejano, de muchos términos oronímicos. Berdoulay (1982) ya aborda el valor de la metáfora como recurso expresivo en el lenguaje geográfico afirmando que "en la medida que el lenguaje geográfico se fundamenta, en gran parte, en el lenguaje corriente, seria absurdo combatir una forma tan esencial del discurso como es la metáfora". En la Tabla 2 aparecen las principales tipologías orográficas (relieve positivo, negativo, neutro y litoral, además del talasonímico o submarino) que son identificadas mediante una rica terminología formada por los correspondientes genéricos toponímicos además de otras informaciones de índole similar presentes en los nombres de lugar. También se reflejan los porcentajes obtenidos en la toponimia balear.

Respecto al relieve positivo y en base a las diversas magnitudes, se puede distinguir entre macro, meso y microrelieve jerarquizado a partir de su propia nomenclatura. En las grandes formas del relieve, precisamente gracias a sus mayores dimensiones, la propia toponimia detecta algunas de sus partes que mejor se distinguen, ya sea por su posición o su relevancia, como es el caso de cimas y contrafuertes.

Los topónimos identifican también el relieve negativo, aunque en este caso resulta más significativa la forma (alargada, redondeada) y posición (elevada) que la magnitud. En cambio, bajo la denominación de relieve neutro (ni positivo ni negativo) se engloban una serie de morfologías que se alejan de la taxonomía anterior al caracterizarse por otras cualidades (verticalidad, inclinación, horizontalidad y escalonamiento).

La toponimia relativa al relieve litoral merece tratamiento aparte, tanto por su singularidad, al identificar morfologías fronterizas con el mar de cuya interacción surgen sus particulares tipologías producto de la aparente invasión del espacio 
terrestre emergido en el mar (positivas o convexidades de la costa) como de la intrusión marina sobre la capa litosférica (concavidades de la costa), a las que cabe añadir la diversidad de nombres que identifican los diversos espacios terrestres aislados cuya característica común es la de estar rodeados por el mar.

Tabla 2. Orónimos: la morfología del terreno.

\begin{tabular}{|c|c|c|}
\hline \multicolumn{3}{|c|}{ Orónimos: la morfología del terreno } \\
\hline \multirow{5}{*}{$\begin{array}{l}\text { Relieve positivo } \\
(24 \%)\end{array}$} & \multirow{2}{*}{$\begin{array}{l}\text { Macrorelieve } \\
(28 \%)\end{array}$} & Cimas $(38 \%)$ \\
\hline & & Contrafuertes $(62 \%)$ \\
\hline & \multicolumn{2}{|c|}{ Mesorelieve (12\%) } \\
\hline & \multicolumn{2}{|c|}{ Microrelieve (21\%) } \\
\hline & \multicolumn{2}{|c|}{ Otros $(39 \%)$} \\
\hline \multirow{3}{*}{$\begin{array}{l}\text { Relieve negativo } \\
(9 \%)\end{array}$} & \multicolumn{2}{|c|}{ Depresiones elevadas $(21 \%)$} \\
\hline & \multicolumn{2}{|c|}{ Depresiones alargadas $(64 \%)$} \\
\hline & \multicolumn{2}{|c|}{ Depresiones redondeadas $(15 \%)$} \\
\hline \multirow{4}{*}{$\begin{array}{l}\text { Relieve neutro } \\
(21 \%)\end{array}$} & \multicolumn{2}{|c|}{ Relieve vertical $(27 \%)$} \\
\hline & \multicolumn{2}{|c|}{ Relieve inclinado (39\%) } \\
\hline & \multicolumn{2}{|c|}{ Relieve horizontal (20\%) } \\
\hline & \multicolumn{2}{|c|}{ Relieve escalonado (14\%) } \\
\hline \multirow{4}{*}{$\begin{array}{l}\text { Relieve litoral } \\
(23 \%)\end{array}$} & \multicolumn{2}{|c|}{ Positivo (convexidades de la costa) $(30 \%)$} \\
\hline & \multicolumn{2}{|c|}{ Negativo (concavidades de la costa) $(43 \%)$} \\
\hline & \multicolumn{2}{|c|}{ Aislado $(16 \%)$} \\
\hline & \multicolumn{2}{|c|}{ Áreas costeras $(11 \%)$} \\
\hline \multirow{6}{*}{$\begin{array}{l}\text { Talasónimos: relieve } \\
\text { submarino } \\
(23 \%)\end{array}$} & \multicolumn{2}{|c|}{ Términos generales (39\%) } \\
\hline & \multicolumn{2}{|c|}{ Relieve submarino positivo (29\%) } \\
\hline & \multicolumn{2}{|c|}{ Relieve submarino negativo (7\%) } \\
\hline & \multicolumn{2}{|c|}{ Composición del suelo submarino (9\%) } \\
\hline & \multicolumn{2}{|c|}{ Relieve litoral sumergido (12\%) } \\
\hline & \multicolumn{2}{|l|}{ Otros $(4 \%)$} \\
\hline
\end{tabular}

Fuente: Elaboración propia, a partir del MTB 1:5.000

Al penetrar en el espacio sumergido, más desconocido por el hombre, nos adentramos en la talasonimia sumergida, buena parte de la cual sigue los mismos patrones morfológicos que el relieve emergido (relieve submarino positivo y negativo), aunque otra parte se refiere a aspectos generales, a menudo descriptivos de la vegetación y ecosistemas submarinos, así como de composición del suelo submarino o de formas orográficas que, por su cercanía al litoral, se sitúan a escasa profundidad y su protagonismo toponímico se debe fundamentalmente al potencial peligro que suponen para la navegación. 


\subsection{La geotoponimia: composición y alteración del terreno}

También relativos al sustrato físico del paisaje, al biótopo, y muy ligados a la orografía, aparecen nombres de lugar que de alguna forma hacen referencia a los materiales que afloran en la superficie de la litosfera. Se trata, en conjunto, de los geotopónimos (Tabla 3), en los que el sustrato material es protagonista.

Tabla 3. Geotopónimos: la composición y alteración del terreno (\% en las Islas Baleares)

\begin{tabular}{|l|l|l|}
\hline \multicolumn{3}{|c|}{ Geotopónimos: la composición y alteración del terreno } \\
\hline \multirow{3}{*}{$\begin{array}{l}\text { Composición del terreno } \\
(56 \%)\end{array}$} & $\begin{array}{l}\text { Pétrea } \\
(76 \%)\end{array}$ & \multicolumn{1}{|c|}{ Dura (86\%) } \\
\cline { 2 - 3 } & Alanda (14\%) \\
\cline { 2 - 3 } & Arenosa (9\%) \\
\cline { 2 - 3 } & Terrosa (12\%) \\
\cline { 2 - 3 } & Otras (3\%) \\
\hline $\begin{array}{l}\text { Alteración natural del } \\
\text { medio } \\
(44 \%)\end{array}$ & Erosión & Marina (10\%) \\
\cline { 3 - 3 } & $(80 \%)$ & Subterránea (46\%) \\
& & Superficial (44\%) \\
\cline { 2 - 3 } & \multicolumn{2}{|l|}{ Desprendimientos (20\%) } \\
\hline
\end{tabular}

Fuente: Elaboración propia, a partir del MTB 1:5.000

De connotaciones geológicas y geomorfológicas, pueden informar sobre los diversos materiales cuya composición resulta predominante en el terreno $(56 \%$ de los geotopónimos baleares) o sobre los procesos que alteran su fisonomía originando morfologías remodeladoras del paisaje natural ( $44 \%$ en Baleares).

Mientras el primer grupo presenta como principal rasgo común el de dar a conocer de manera simple, pero efectiva, la composición edafológica y pedológica; en el segundo hallamos los geotopónimos que indican de forma explícita la alteración natural del medio producida por la acción, a veces conjunta, de factores físicos o abióticos, dando idea de las distintas formas que surgen de esta intervención superficial, subterránea o marina: desde la aparición de macroformas materializadas en paisajes derruidos y desmenuzados que han sufrido el arranque de material, hasta microformas o fisuras longitudinales, pasando por desprendimientos, a veces masivos, del relieve más elevado donde se hace patente la fuerza de la gravedad, o formas superficiales y subterráneas producidas por la acción desgastadora del agua (Figura 1). En las Islas Baleares, destaca la presencia pétrea, con un $76 \%$ de los geotopónimos de su grupo; y la alusión a la erosión subterránea, mayoritaria con un $46 \%$ de los geotopónimos relativos a dicho tipo de alteración. 
Figura 1. Es Rellar. Un modelado exocárstico identificado mediante la metáfora toponímica.

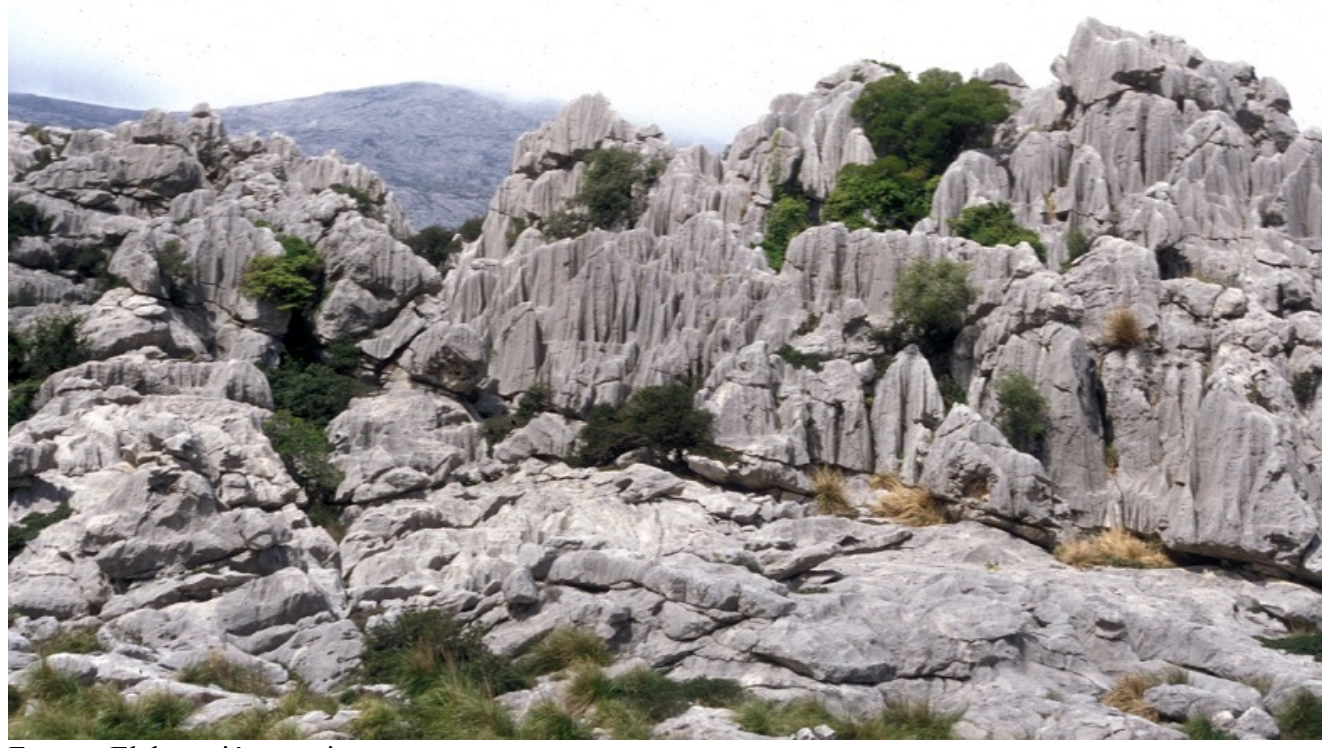

Fuente: Elaboración propia.

\subsection{La hidronimia: la presencia del agua}

La presencia, a veces escasa y otras abundante, del agua sobre la superficie terrestre constituye uno de los factores físicos más importantes en la configuración del paisaje por lo que, lógicamente, no ha pasado desapercibido por el hombre, quien, por el carácter vital de la hidrología natural, ha atesorado y transmitido su identificación y localización a lo largo del tiempo y las generaciones.

Tabla 4. Hidrónimos: la presencia del agua

\begin{tabular}{|l|l|}
\hline \multicolumn{2}{|c|}{ Hidrónimos: la presencia del agua } \\
\hline $\begin{array}{l}\text { Hidrónimos terrestes } \\
(88 \%)\end{array}$ & Surgencias de agua (24\%) \\
\cline { 2 - 2 } & Aguas estancadas (41\%) \\
\cline { 2 - 2 } & Cursos de agua (33\%) \\
\cline { 2 - 2 } & Escasez de agua (2\%) \\
\hline \multicolumn{2}{|c|}{ Hidrónimos marinos (12\%) } \\
\hline
\end{tabular}

Fuente: Elaboración propia, a partir del MTB 1:5.000

La Tabla 4 refleja la diversidad tipológica de los hidrónimos naturales -que no implican intervención humana- distinguiendo entre los nombres relativos a la hidrología terrestre, o interior, de la marina. Los primeros, además de mayoritarios 
( $88 \%$ de los baleares), se clasifican en surgencias (Figura 2), estancamientos y cursos (en ambos casos, temporales o permanentes), a los que se pueden añadir los referidos a la escasez de agua. Capítulo aparte merecen los hidrónimos marinos, temáticamente situados en una confusa frontera junto a ciertos talasónimos e hidrónimos litorales. En la Tabla 4 se indica la distribución porcentual de la hidronimia balear y, en particular, la terrestre por tipologías.

Figura 2. Fonts Ufanes. Un singular ejemplo de surgencia vauclusiana.

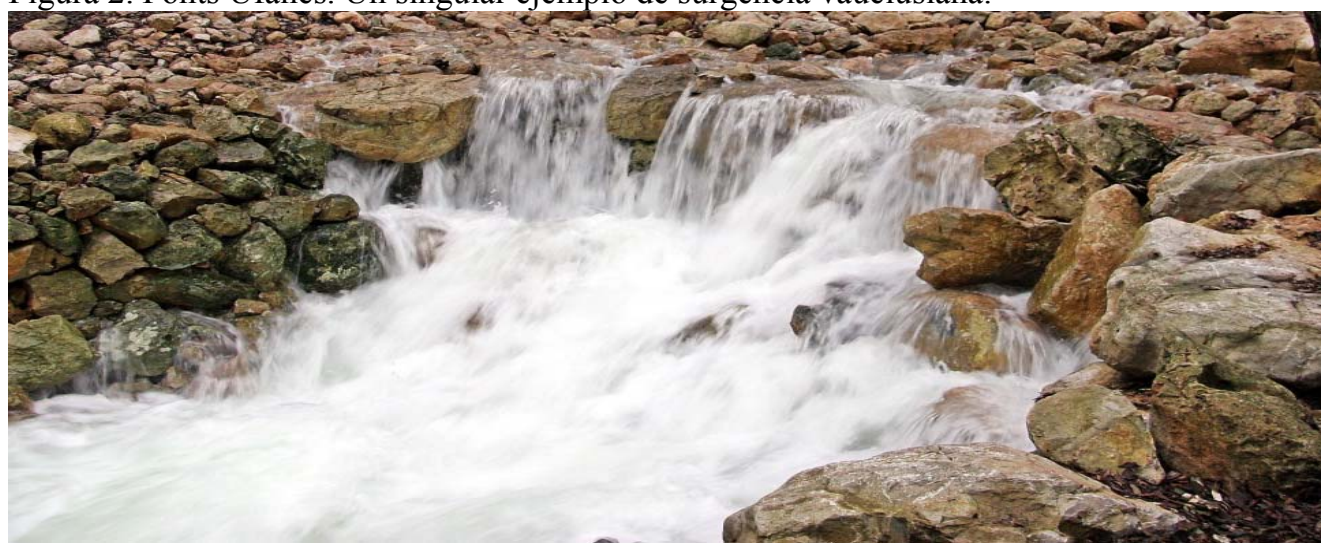

Fuente: Elaboración propia.

\subsection{La biotoponimia (fitotoponimia y zootoponimia): la naturaleza viva}

Además de informar sobre los elementos que configuran el biótopo, los nombres de lugar también pueden hacer referencia a la presencia de los seres vivos (Tabla 5) hasta el punto de ocupar un lugar destacado en el conjunto de la toponimia relativa a la naturaleza susceptible de ser dividida entre el reino vegetal (flora) y animal (fauna) que en conjunto denominamos biotoponimia.

Los nombres de lugar alusivos a las plantas (fitotoponimia) son mayoritarios $(74 \%$ de los biotopónimos baleares), ya sea para referirse, en forma singular o plural, a la presencia actual o pretérita de alguna especie arbórea, arbustiva o herbácea. A veces los fitotopónimos, más concretamente aún, denotan la abundancia de la cobertura vegetal, tanto para identificar comunidades vegetales características de determinados ecosistemas como a las que reflejan el predominio de una especie. En otras ocasiones, en cambio, la referencia a la presencia vegetal es inversa e indirecta, destacando la ausencia de la vegetación a causa de la deforestación y de los incendios forestales, frecuentemente debidos a la acción antrópica (Figura 3). 
Tabla 5. Biotopónimos: la parte viva de la naturaleza

\begin{tabular}{|c|c|c|}
\hline \multicolumn{3}{|c|}{ Biotopónimos: la parte viva de la naturaleza } \\
\hline \multirow{5}{*}{$\begin{array}{c}\text { Fitotopónimos: } \\
\text { la vegetación natural } \\
\qquad(74 \%)\end{array}$} & \multirow[t]{3}{*}{$\begin{array}{c}\text { Presencia de vegetación } \\
(87 \%)\end{array}$} & $\begin{array}{l}\text { Términos generales: comunidades vegetales } \\
(17 \%)\end{array}$ \\
\hline & & Predominio o abundancia de una especie ( $82 \%)$ \\
\hline & & Ejemplares singulares $(1 \%)$ \\
\hline & \multirow{2}{*}{$\begin{array}{c}\text { Ausencia de vegetación } \\
\qquad(13 \%)\end{array}$} & Deforestación (82\%) \\
\hline & & Incendios forestales $(18 \%)$ \\
\hline \multirow{8}{*}{$\begin{array}{l}\text { Zootopónimos: la fauna } \\
\qquad(26 \%)\end{array}$} & \multicolumn{2}{|l|}{ Términos generales $(24 \%)$} \\
\hline & \multirow{7}{*}{$\begin{array}{l}\text { Abundancia de una especie } \\
\qquad(76 \%)\end{array}$} & Mamíferos (4\%) \\
\hline & & Aves $(41 \%)$ \\
\hline & & Reptiles (4\%) \\
\hline & & Anfibios (5\%) \\
\hline & & Insectos $(5 \%)$ \\
\hline & & Moluscos $(5 \%)$ \\
\hline & & Peces y crustáceos $(36 \%)$ \\
\hline
\end{tabular}

Fuente: Elaboración propia, a partir del MTB 1:5.000

Figura 3. Illa des Bosc. El contraste del topónimo constata la deforestación.

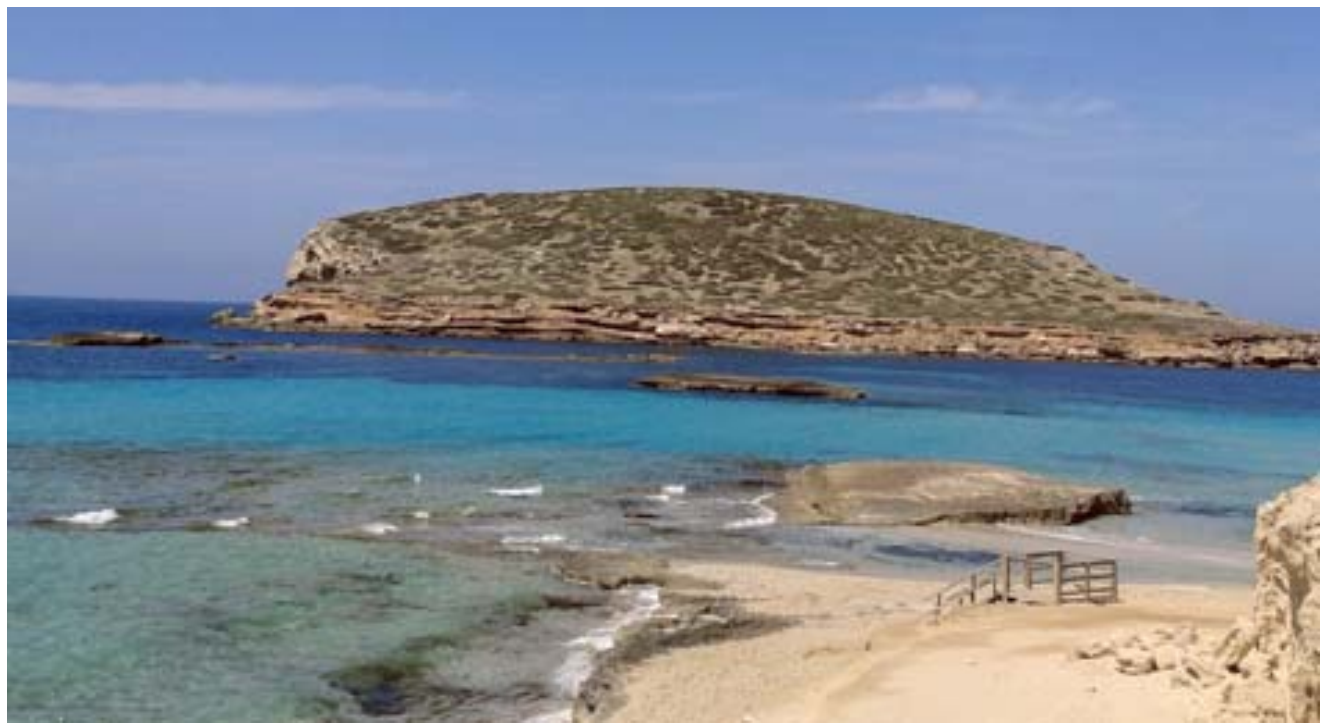

Fuente: Elaboración propia.

En el caso de las Baleares, sólo un 13\% de los fitotopónimos se refieren a la ausencia de vegetación como consecuencia, según expresan un $82 \%$ de dichos casos, de los incendios forestales. En cambio, la presencia de vegetación en la toponimia se 
distribuye a través de las tres fórmulas recogidas en la Tabla 5 entre las que destaca, en las Baleares, con un $82 \%$ de los fitotopónimos de su conjunto, el grupo alusivo al predominio o abundancia de una especie.

En el conjunto de la biotoponimia, los zootopónimos forman un subgrupo minoritario (24\% en Baleares). La movilidad de la fauna no sólo dificulta algunos aspectos de su estudio zoológico, como el censo y la cartografía, sino que también explica las dificultades para fijar su presencia en un lugar mediante la toponimia que, cuando aparece, puede convertirse, al menos en ciertos casos, en ciencia auxiliar para naturalistas, biológos y biogeógrafos. En Baleares, el 76\% de los zootopónimos se refieren a la presencia o abundancia de una determinada especie, cuya distribución por clases refleja la mayor presencia de aves y peces.

\subsection{La toponimia meteorológica}

Algunos meteoros también dejan su huella en la toponimia.

Tabla 6. La meteorología

\begin{tabular}{|l|l|}
\hline \multicolumn{2}{|c|}{ La meteorología } \\
\hline $\begin{array}{l}\text { Viento } \\
(50 \%)\end{array}$ & $\begin{array}{c}\text { Acústica litoral por la acción del } \\
\text { viento y el agua }\end{array}$ \\
\hline Nieve $(40 \%)$ \\
\hline Rayos $(10 \%)$ \\
\hline
\end{tabular}

Fuente: Elaboración propia a partir del MTB 1:5.000

Figura 4. Sa Vaca. Una oquedad litoral que "muge" por el azote de los temporales.

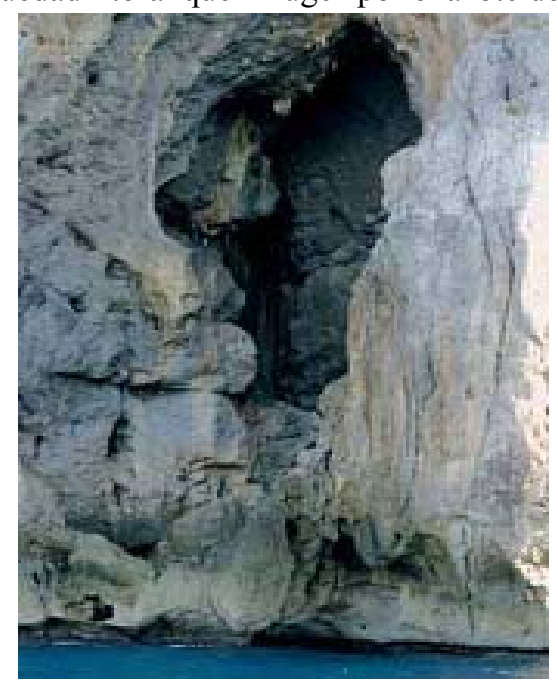

Fuente: Elaboración propia. 
Tal como refleja la Tabla 6, en la de las Baleares el viento es el más destacado y aparece identificando aquellos lugares cuya localización favorece tanto la intensidad como la frecuencia del viento, entre los que abundan los enclaves litorales, en los que a la acción y movimiento del aire se suma la del agua, produciendo en ocasiones fenómenos acústicos igualmente reflejados en los topónimos, en algunos casos utilizando el recurso de la metáfora (Figura 4). Menos frecuentes son los casos que aluden a la presencia, episódica, de nieve y de rayos cuando han descargado produciendo algún tipo de destrozo o accidente (Ordinas, 2002).

\subsection{La toponimia relativa a la exposición solar}

Existen topónimos que de forma más o menos directa hacen referencia a la calidad que presentan algunos lugares, especialmente las vertientes, debido a su orientación o exposición solar, pues la posición respecto al sol constituye un importante aspecto en su consideración (Figura 5). Dependiendo de la orientación, la incidencia de los rayos solares varía sensiblemente, y con el mayor o menor grado de insolación, también se ven afectadas la humedad y la temperatura.

Tabla 7. La exposición solar

\begin{tabular}{|l|}
\hline La exposición solar \\
\hline Solanas (50\%) \\
\hline Umbrías (50\%) \\
\hline
\end{tabular}

Fuente: Elaboración propia, a partir del MTB 1:5.000

Figura 5. Cala Solana.

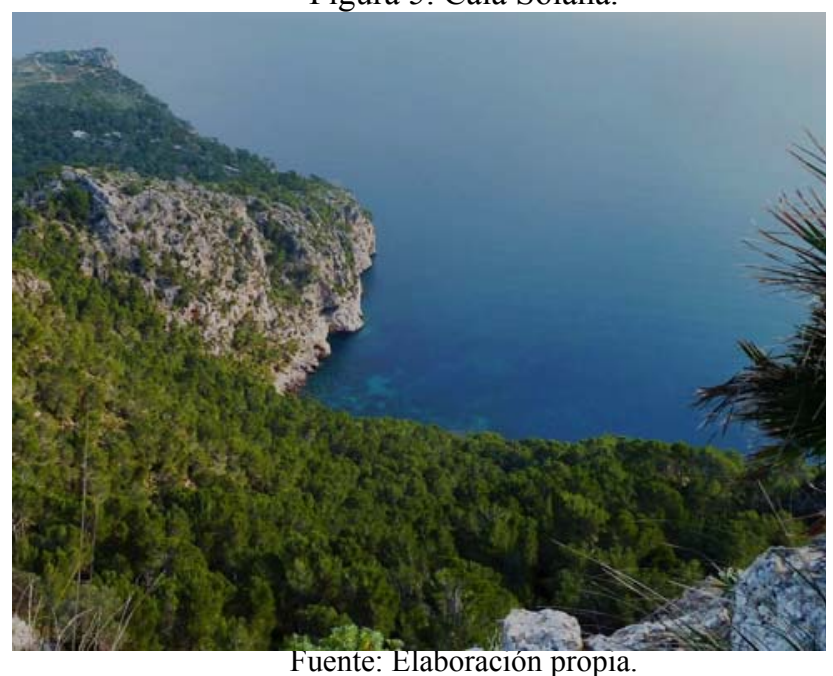

La ladera encarada al sol, al sur, será más seca y menos fría que la que le dé la espalda; mientras que ésta última, por el contrario, se caracterizará por su mayor 
humedad, ser umbría, sombreada y menos calurosa. De ahí que las vertientes enfiladas hacia el sur sean las preferidas tanto para el cultivo como para el establecimiento y orientación de la casa. Tal dicotomía queda reflejada en la Tabla 7 a partir de las referencias toponímicas que se refieren a solanas y umbrías y otros términos asociados, con proporciones similares en el caso de las Baleares.

Un caso especial lo constituyen los llamados relojes solares naturales (Figura 6), enclaves donde la observación del hombre le ha permitido establecer una determinada hora solar, preferentemente la del mediodía, al coincidir este preciso instante temporal con la plena iluminación de un accidente geográfico concreto.

Figura 6. El reloj natural de la Penya des Migdia marca con precisión el mediodía solar.

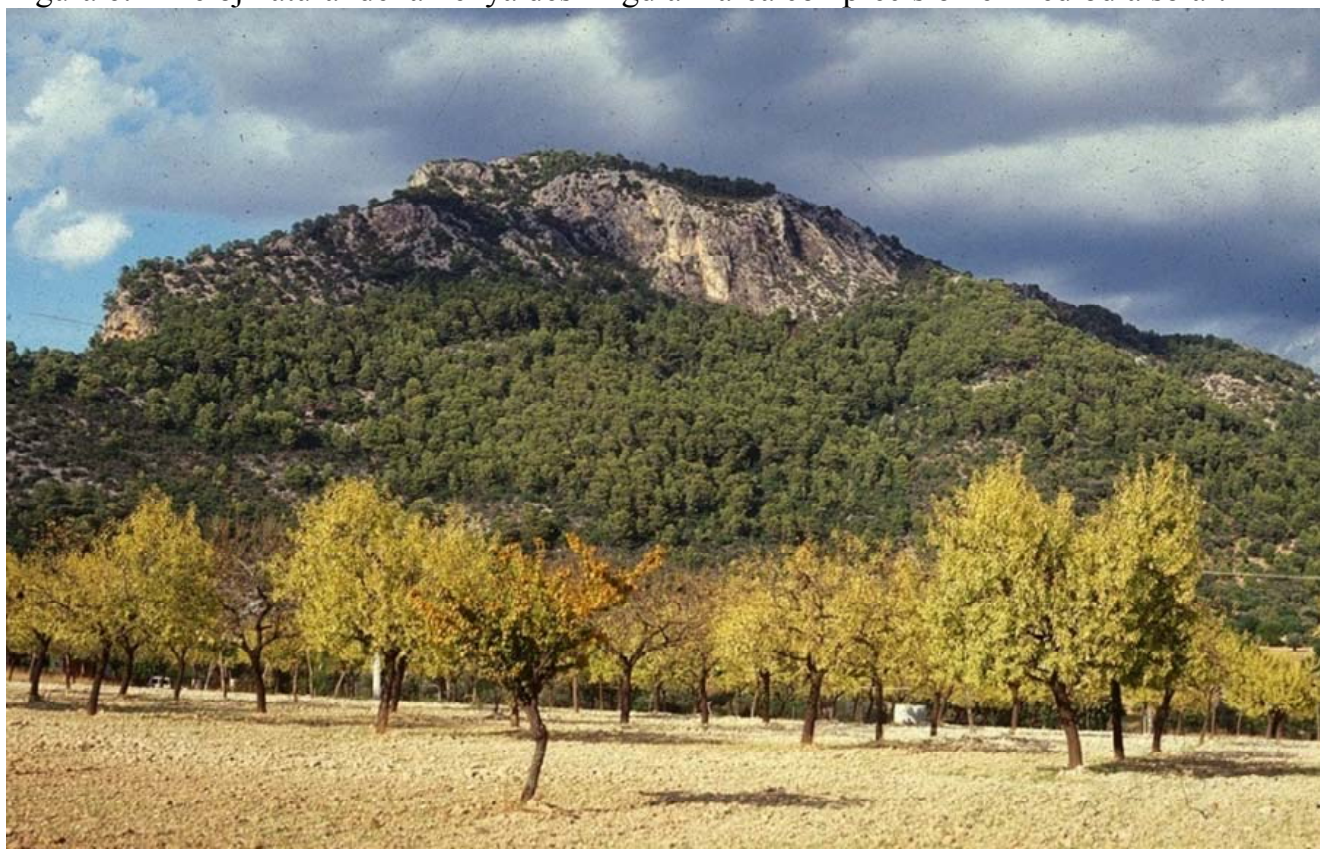

Fuente: Elaboración propia.

\subsection{La toponimia sobre la percepción del paisaje}

Finalmente, a la hora de poner nombre a los lugares, tanto la apreciación estética del paisaje como la sensación de bienestar no cuentan con gran tradición ni representatividad en la toponimia popular -excepto las correspondientes excepciones que confirman la regla- ya que en todo caso su motivación es reciente y va asociada a la neotoponimia surgida del ocio y del fenómeno turístico (Figura 7). Cuesta creer que muchos lugares, a pesar de su reconocida belleza natural, no fuesen percibidos por los antiguos pobladores en un sentido lúdico o paradisíaco. A pesar de ello existen 
topónimos alusivos al paisaje e incluso a su belleza (Tabla 8), pero muchos suelen estar desprovistos de connotaciones estéticas $y$ hacen referencia, simple $y$ exclusivamente, a la visión panorámica del paisaje, no para su contemplación lúdica sino con una clara finalidad práctica: la vigilancia, frecuentemente asociada, a la defensa.

Tabla 8. La percepción del paisaje

\begin{tabular}{|l|}
\hline \multicolumn{1}{|c|}{ Percepción del paisaje } \\
\hline La visión panorámica del paisaje (55\%) \\
\hline Belleza del paisaje (9\%) \\
\hline Cromotoponímia: los colores del paisaje (36\%) \\
\hline
\end{tabular}

Fuente: Elaboración propia a partir del MTB 1:5.000

Figura 7. Desde el Mirador de ses Barques se contempla la belleza del paisaje en torno al Puerto de Sóller.

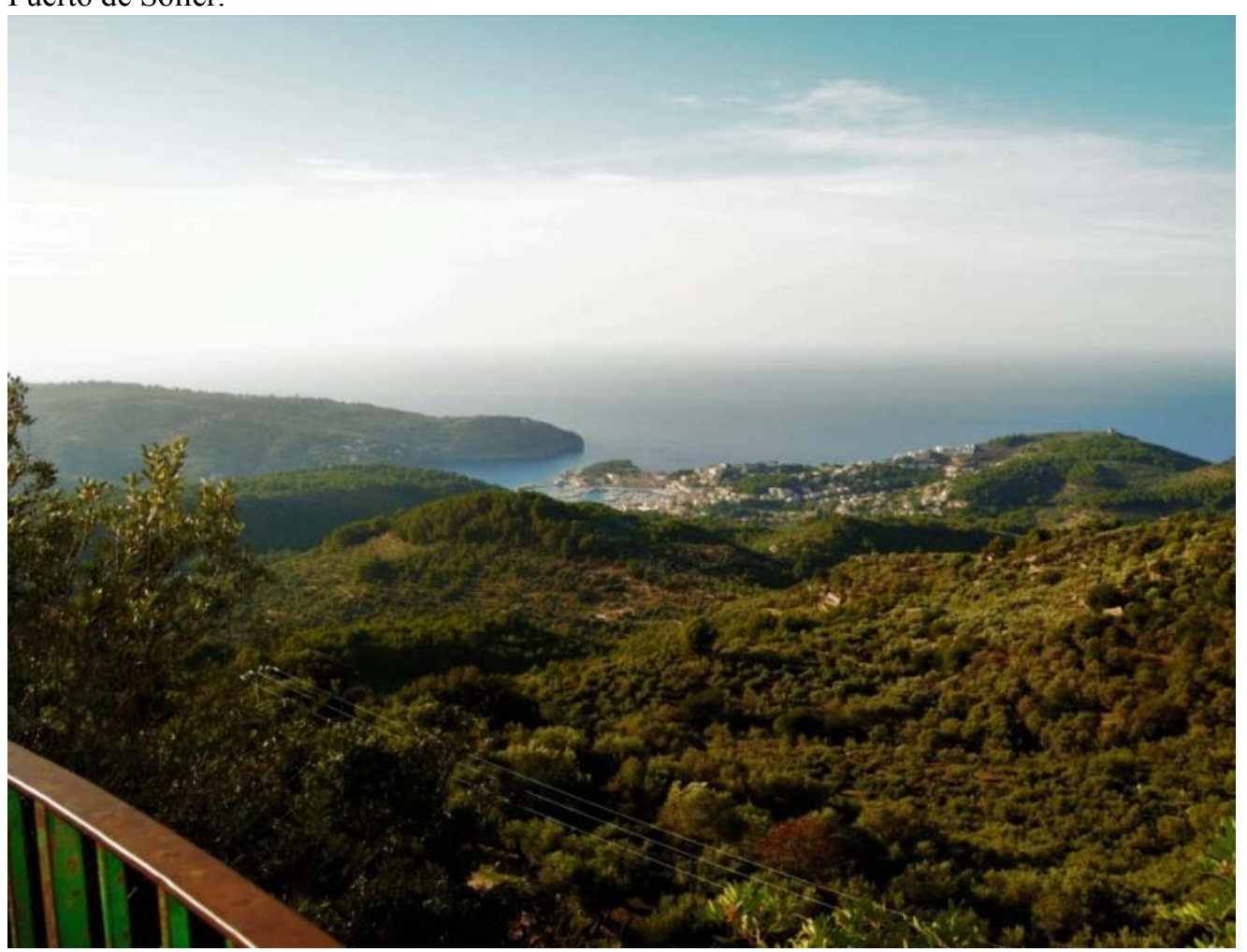

Fuente: Elaboración propia.

En otros casos, el cromatismo del paisaje queda también reflejado en los nombres de lugar que los identifican a partir de los colores que son así percibidos como el 
rasgo más característico. En buena parte de estos cromotopónimos, la razón última o etiología se encuentra en los materiales, únicos o predominantes, del lugar designado (Figura 8), por lo que estos topónimos también pueden ser clasificados, según cada caso, como geotopónimos, hidrónimos, fitotopónimos, etc. En la Tabla 8 se muestra la distribución en la toponimia balear para cada uno de estos aspectos.

Figura 8. Punta Roja. Los cromotopónimos describen los colores del paisaje.

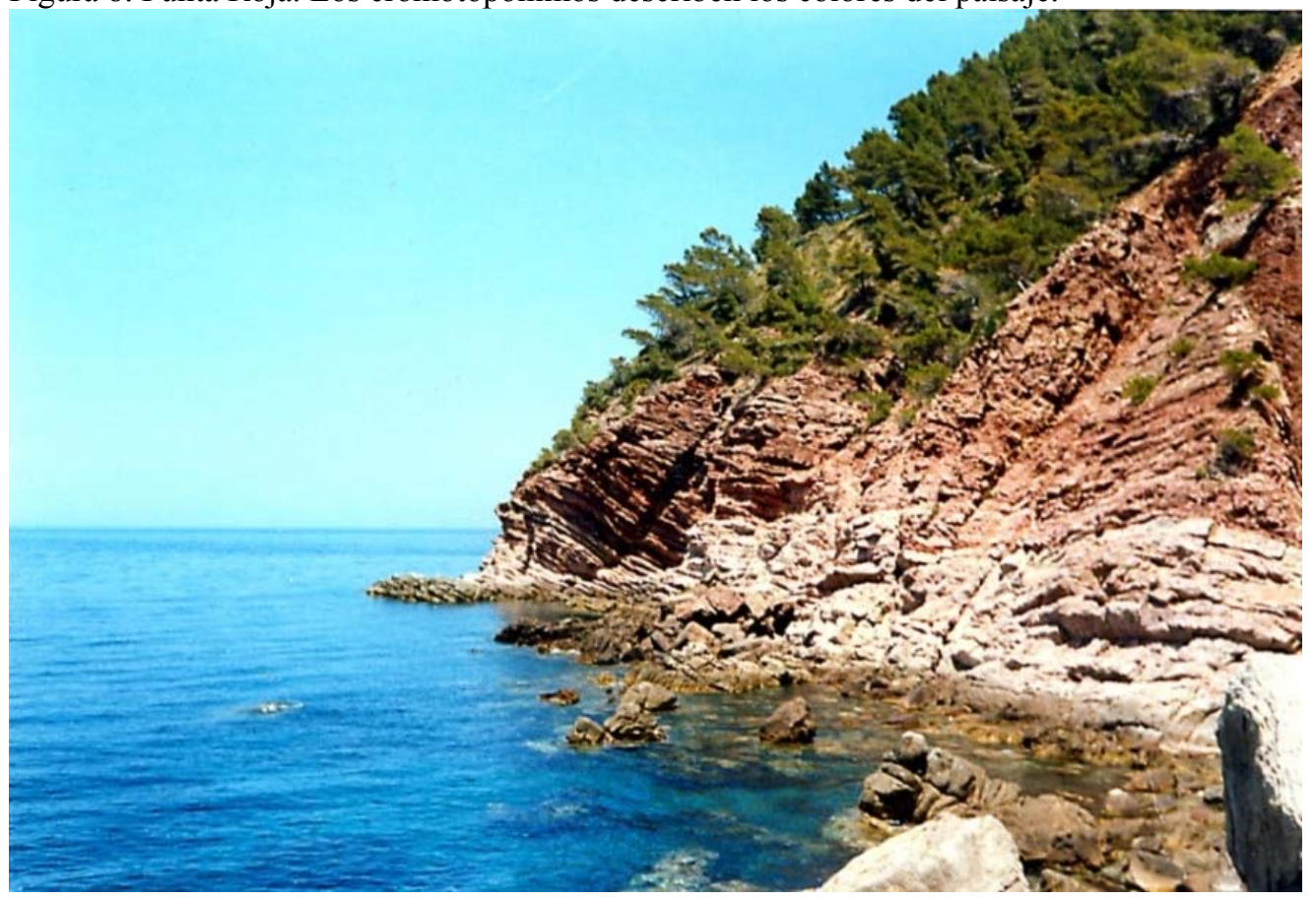

Fuente: Elaboración propia.

\section{Conclusiones}

Tanto por su naturaleza como por sus características, se evidencia el importante potencial didáctico de la toponimia aplicada a la enseñanza de la geografía, en general, y del paisaje natural y la geografía física en particular, en cualquiera de los niveles educativos. La utilización didáctica de los topónimos puede orientar e incluso protagonizar los procesos educativos con el objeto de llegar a conseguir una educación integral del individuo y con claras posibilidades de aplicación en un aprendizaje holístico y una enseñanza activa enfocada al estudio del entorno y la enseñanza por descubrimiento. El análisis atento de los nombres de lugar no sólo desvela las claves para la observación e interpretación del paisaje (actual y pretérito) 
sino que facilita además la observación directa del medio, al resultar imprescindible el trabajo de campo respaldado con el manejo de fuentes cartográficas, orales y documentales.

Siguiendo la misma línea de opinión de otros geógrafos (Rosselló, 2004), es posible aprovechar el enorme potencial didáctico de los antiguos y tradicionales nombres geográficos, emblemáticos y auténticos representantes del espacio que identifican. A través del profundo y pormenorizado conocimiento del territorio y su geografía al que se llega a través del estudio de su toponimia, se consigue aún, como objetivo actitudinal a añadir a los conceptuales y procedimentales ya descritos, otro valor añadido: la valoración del paisaje y de los elementos patrimoniales en él presentes, naturales y culturales.

Aunque comprobamos como la toponimia se constituye en una herramienta pedagógica de gran valor, generalmente ha sido relegada e ignorada en su potencial uso como recurso didáctico al ser asociada a antiguas y obsoletas fórmulas de enseñanza fundamentadas en el abuso del ejercicio de la memoria. Nuestro objetivo es el de contribuir a redescubrir para el colectivo docente su utilidad para que pueda ser aplicada en la enseñanza del paisaje natural con renovadas técnicas y aplicaciones. En esta línea se han planteado iniciativas (Dorion, 1986) que destacan las bondades, y competencias, que la toponimia aporta a la enseñanza de la geografía y que alientan a los docentes a coordinar entre sus alumnos la realización de inventarios toponímicos de sus respectivos territorios. En esta tarea, los equipos de estudiantes se benefician de la experimentación en métodos de encuesta, se familiarizan con el terreno y con el manejo de las fuentes cartográficas y documentales, a la par que descubren la geografía regional mejorando el conocimiento del territorio y del paisaje natural.

De esta forma, a través de la toponimia no sólo es posible aprender geografía, al igual que otras ciencias sociales, sino que es recomendable tanto por su utilidad en múltiples aspectos de la vida cotidiana como para conseguir una formación integral del alumnado que experimentará la interdisciplinariedad tanto en el manejo de los contenidos como en el de las técnicas auxiliares. La clasificación y sistematización aportadas en base a nuestra experiencia en la toponimia y la geografía balear, pretenden contribuir a desvelar el potencial didáctico de la toponimia en los múltiples contenidos relativos a la enseñanza de la geografía física y del paisaje natural al tiempo que facilitar su utilización pedagógica en el colectivo docente.

\section{Bibliografía}

Alderman, D.H. (2000): A Street Fit for a King: Naming Places and Commemoration in the American South. Professional Geographer, 52: 4, 672-684.

Berdoulay, V. (1982): La mètaphore organiciste. Contribution à l'étude du langage des géographers, Annales de Géographie, 507, 573-586.

Claval, P. (1995): La geographie culturelle. París, Nathan editions. 
Cohen, S.B.; Kliot, N. (1992): Place-Names in Israel's Ideological Struggle over the Administered Territories. Annals of the Association of American Geographers, 82:4, 653680.

Darby, H.C. (1957): Place names and geography. The Geographical Journal, 123, 387-392.

Dorion, H. (1984): Las relaciones entre la Toponimia y otras Ciencias Sociales, Québec, 103108.

Dorion, H. (1986): La toponymie et l'enseignement de la Geógraphie. Cahiers de geógraphie du Québec, 30:81,429-432.

Dorion, H. (2007): Toponymie et conscience territoriale. http://www.toponymiefrancophone.org/DivFranco/pdf/Toponymie $\% 20$ et $\% 20$ conscience $\%$ 20terriroriale.pdf

Enica, S. (2011): The importance of the place-names/toponyms in Geography Didactics. Lucrarile Seminaruliu Geografic “Dimitri Cantemir”, 31, 235-243.

Friera, F. (1992): Utilidad de la toponimia para el conocimiento del entorno. Lletres asturianes: Boletín Oficial de l'Academia de la Llingua Asturiana, 45, 35-44.

Heikkila, K.A. (1995): Teaching Through Toponymy: Using Indigenous Place-Names. En Outdoor Science Camps, Thesis Master of Arts in Natural Resources and Environmental Studies (Geograpy).

Ordinas, A. (2000): Geografia i Toponímia a les Illes Balears. La terminologia geogràfica en els noms de lloc. Mallorca, Ed. Moll.

Ordinas, A. (2002): La fixació dels elements climàtics en el paisatge de les Illes Balears a través de la toponímia. En GUIJARRO, J.A.; GRIMALT, M.; LAITA, M. y ALONSO, S. (eds.): El agua y el clima.Publicaciones de la Asociación Española de Climatología (AEC), 3, 495-502.

Ordinas, A. (2004): Els ensenyaments fisiogràfics de la toponímia. Genèrics orogràfics del Migjorn. En FORNÓS, J.J.; OBRADOR, A.; ROSSELLÓ, V.M.; (eds): Història natural del Migjorn de Menorca: el medi físic i l'influx humà. Monografies de la Societat d'Història Natural de les Balears, 11, 315-326.

Ordinas, A. y Binimelis, J. (2002): Vindicación de la toponimia como instrumento para el estudio del cambio rural. Rururbanización y neotoponimia en los municipios de Selva e Inca (Mallorca). En ASOCIACIÓN DE GEÓGRAFOS ESPAÑOLES (eds.): Los espacios rurales entre el hoy y el mañana: Actas del XI Coloquio de Geografía Rural. Santander, Universidad de Cantabria, 285-293.

Parella, M. (2008): Informació toponímica: tendències actuals i futures en un context internacional. Revista Catalana de Geografia. Jornada de treball: Toponímia cartogràfica. Tendències actuals i futures. XII, 34.

Raisz, E. (1985): Cartografía. Barcelona, Omega.

Rose-Redwood, R.; Alderman, D.; Azaryahu, M. (2010): Geographies of toponymic inscription: new directions in critical place-name studies. Prog Hum Geogr, 34:4, 453-570. Rosselló, V.M. (2004): Toponímia, geografia i cartografia, València, Universitat de València. Sauer, C.O. (1956): The Education of a Geographer. Annals of the Association of American Geographers, 46, 287-299. 
Sauer, C.O. (1985): La educación de un geógrafo. En GARCÍA RAMON, M. D. (ed.): Teoría y método en la geografía humana anglosajona. Barcelona, Ariel, 38-53.

Tort, J. (2000): La geografia, els noms de lloc i la descripció del territori. En MATEU, J.F.; CASANOVA, E. (eds.): Estudis de Toponímia Valenciana. Valencia, Denes, 491-497.

Tort, J. (2001): La toponímia com a camp de coneixement interdisciplinari. Algunes bases teòriques i epistemològiques per a l'estudi dels noms de lloc. Scripta Nova, 86.

Tort, J. (2002): La toponímia del Baix Camp. Una interpretació geogràfica. Reus, Associació d'Estudis Reusencs.

Tort, J. (2003): Toponimia y marginalidad geográfica. Los nombres de lugar como reflejo de una interpretación del espacio. Scripta Nova, 138.

Tuan, Y.F. (1974). Topofilia. A study of environmental perception, attitides and values. Nueva York, Columbia University Press.

Valenzuela, E. (2010): ¿Es posible aprender Geografía a través de la toponimia?. Investigación Universitaria Multidisciplinaria, 9, 16-26.

Vidal De La Blache, P. (1888-1889): Des divisions fondamentales du sol français. Butlletin Littéraire, II, 1-7, 49-57.

West, R.C. (1954): The Term "Bayou" in the United States: A Study in the Geography of Place Names. Annals of the Association of American Geographers, 44:1, 63-74. 